53

COLONIC WATER ABSORPTION IS IMPAIRED DURING SMALL INTESTINAL

Nocerino A., Cuandalini S., Bernardo I., lafusco M., Rubino A.
Dept of Pediatrics, 2nd Medical School Univ. of Naples

The effects of Cr on small intestinal transport of water and electrolytes are are altered in the colon when $C r$ is present only in the small intestine. Aiming at defining the role of the colon in handling of water and electrolyte transport in such circumstances, we have measured water and ion transport in vivo in rat jejunal and colonic separate loops. Two groups of rats were investigated: in one, of both loops for the ensuing 3 hours with a modified Ringer solution; the other (control) was likewise handled, but without any previous instillation; of $\mathrm{Cr}$. Results: In CT animals, water transport in the jejunum was significantly (p/0.01) shifted toward secretion $(-0.77 \pm 2.0 \mathrm{ul} / \mathrm{min} g$ wet weight vs. $13.19 \pm 1.9$ in the
controls). Similarly, in CT animals, the simultaneously measued water the controls). Similarly, in CI animals, the simultaneously measured water transport to the colon was al so significantly $(p(0.01)$ shifted toward secretion $(0.6 \pm 2,4$ In conclusion: our data shows that the colon contributes to the overali intestinal secretion seen in cholera infection, even when CT does not interact with its
mucosa. It remains to be seen whether such observation relates oniy to $C T$-elicited mucosa. It remains to be seen whether such observation relates only to CT-elicited
small intestinal secretion or it represents a general pattern linking small and
large intestinal transport.
G.Boudraaa, M. Touhami, P.Pouchart*, R.Soltana, J.F. Desjeux Institut des Sciences Medicales.

PO denotes episodes of diarrhoea that begin acutely, but persist beyond 15 days. Although the pathophysiology of PD remains unclear, it has been suggested to be related to the composition of the food ingested. The main objective of this study was to compare the clinical outcome in children with clinical failure (weight loss, $5 \%$ and intestinal intolerance) was 30 child dren with $M$ and 26 children with $Y$. The 2 groups were ientical at randomisation (age $=8.2$ months : duration of diarrhea $=20$ days; number of stools $=6.3 /$ day; weight/height $=85 \%)$. Following observations were made. 1) Clinical failure $13(43 \%)$ in group $M$ and only $3(11 \%)$ in group $Y(p<0.01)$. 2) Weight gain was
$44+48 g(x+S E)$ vs $152+95(p<0.02)$ in $M$ and $Y$ respectively 3$)$ Duration of diarrhea was $73+9 \mathrm{hr}$ in $M$ and $40+8$ in $Y$ and $Y$ respectively. 3 ) Duration was $40+8$ in M vs $22+4$ in $Y$. 5 ) Fluid intake was $62+7 \mathrm{ml} / \mathrm{kg} / \mathrm{d}$ in $M$ vs the same in oth groups $i . e .150 \mathrm{ml} / \mathrm{kg} / \mathrm{d}$ in group $i 9$ and $142 \mathrm{ml} / \mathrm{kg} / \mathrm{d}$ in group $Y$. These results demonstrate a clinical advantage of feeding yogurt rather than milk in children with persistent diarrhea.
54 NONINVASIVE URINARY INDICATORS OF CATABOLISM IN RATS G.Schöch, A. Held, G.Sander, H.Topp, G. Heller-Schöch
Forschungsinstitut für Kinderernährung Dortmund, FRG

We aim at measuring whole-body metaboljc activity, especially metabolic imbalance caused e.g. by hunger (Schöch et al, ESPGAN 988, Ped Res 24: 419). Particularly sensitive indicators of me( $\mathrm{m}^{3} \mathrm{Hic}$; (mis, urine and show that $m^{3}$ sured striction (negative $r$ values), whereas $m^{7}$ Gug excretion drops (positive $r$ values) after a transient increase. young rats $(n=11-15 ; 32$ d old on 1 st day of experiment). Food quantity was varied in 3 steps $(0.6-2.2 \mathrm{MJ} / \mathrm{kg} / \mathrm{d})$
(a)

Parameter correlated
to energy intake

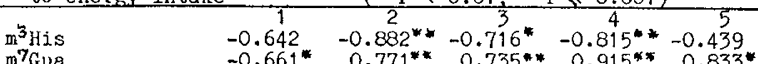

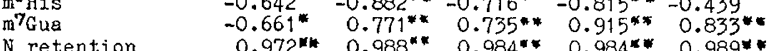
$N$ retention
We conclude that in food deficiency muscle protein is broken down to ensure continued aynthesis of vital proteins; concomitantly, after a transient breakdown of mRNA leading to increased m7 Gua excretion whole-body mRNA turnover is slowed down. Our results rections with decreasing food intakes. Therefore increased $\mathrm{m}^{3} \mathrm{His} /$ ara ratios, which can be measured in spot urine samples, may caused by food deficiency.

\section{PERCUTANEOUS ENDOSCOPIC CONTROLLED GASTROSTOMY (PEG)
FOR ALIMENTATION OF CHILDREN WITH CYSTIC FIBROSIS}

$\frac{\text { B. Rodeck, G. Steinkamp, M. Burdelski, H. von der Hardt }}{\text { Medizinische Hochschule Hannover, FRG }}$ Kinderklinik, Medizinische Hochschule Hannover, FRG

The benefit of a hyperalimentation in patients with cystic fibrosis is well known. Oral hyperalimentation is difficult to perform and gastric tubes are not well accepted by the patients. In a prospective study we investigated whether PEG might be an alternative in the application of hypercaloric diet. So far PEG was performed in 9 children aged from 7,2 to 17,9 years. In 8 patients we have a follow-up of at least 3 months. Those patients entered the study where there was 1. a percentage ideal weight for height (IWH) below $80 \% 2$. and/or no improvement of the IWH above $3 \%$ despite optimal conventional nutrition in a 6 month period. PEG was performed under general anaesthesia according to the method of Keymling ${ }^{\circ}$. Except of two dislocations of the PEG-tube, which were easily corrected, we saw no complications. PEG was well accepted by the patients and their parents. In addition to normal nutrition the children received $1000 \mathrm{kcal}$ bulkage-free diet over night. After 3 months there was a mean increase of IWH of $9 \%(3-12 \%)$, of triceps skin fold thickness of $2,91 \mathrm{~mm}(-0,3-6,9 \mathrm{~mm})$ and of upper arm circumference of $1,88 \mathrm{~cm}(0,9-2,9 \mathrm{~cm})$. From these data we conclude that PEG is a very effective and save procedure in the nutritional therapy in patients with cystic fibrosis.

Keymling M, Schlee P, Wörner W. Die perkutane endoskopisch kontrollierte Gastrostomie. DMW 112:182(1987)

\section{DEFECTIVE JEJUNAL BRUSH BORDER $\mathrm{Na}^{+} / \mathrm{H}^{+}$EXCHANGE IN}

57 IETFEL FAMIITAK, PROTRACTW DIARRHDOA

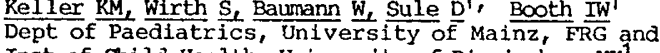
Inst of Child Health, University of Birmingham, UK ${ }^{1}$ The clinical spectrum of disease associated with the recent ly exchange remains poorly defined. We describe a further, lethal case of protracted diarrhoea in a child from a family in whom 2 previous siblings died of protracted diarrhoea at 2 and 11 months. The patient, a boy, was born at term weighing $2.9 \mathrm{~kg}$ and was admitted at $6 \mathrm{~d}$ with profuse watery diarrhoea, severe dehydration and metabolic acidosis. parenteral nutrition was started but the diarrhoea persisted, and he developed severe necrotising entercoolitis requiring an ileostomy. A high-output secretory diarrhoea persisted during 1 l by mouth (ileostomy fecretory diarrhoea persisted during nil by mouth (ileostomy fluid mmol/l: $\left.\mathrm{Na}^{+} 128 ; \mathrm{K}^{+} 10 ; \mathrm{Cl} 96\right)$ and reanastomosis.
Parenteral $\mathrm{Na}^{+}$requilrement was high $(6-10 \mathrm{mmol} / \mathrm{kg} / \mathrm{d})$. Extensive investigation of gastrointestinal function was non-contributory, but transport studies on a jejunal biopsy at $3 \mathrm{mo}$, which showed a mild partial villous atrophy but normal electron microscopy, stimulated glucose uptake by jejunal $\mathrm{BBM}$ vesicles (patient: $107 \mathrm{mmol} / \mathrm{mg}$ proteinj (patient: 15 (SD 111) negligible (patient: 9 pmol/mg protein; control mean: 150 (SD 48)); $\mathrm{Na}^{+}$uptakes at equilibrium (120 min) were normal. The $48)) ; \mathrm{Na}^{+}$uptakes at equilibrium $(120 \mathrm{~min})$ were normal. The
patient died of severe intercurrent infection at $18 \mathrm{mo}$. These patient died of severe intercurrent infection at 18 mo. These
data therefore extend the spectrum of disorders characterised by a specific defect in $\mathrm{Na}^{+} / \mathrm{H}^{+}$exchange.

\section{ABEBA AND STOCKHOLM Rutger Bennet,
Nebiat Tafari} St Göran's Children's Hospital, Stockholm, and Ethio-Swedish Children's Hospital, Addis Abeba.

AIMS: To compare the aerobic and anaerobic intestinal microflora of newborn infants with and without antibiotic treatment and also to describe any relationships between presence of anaerobic bacteria and colonization by potentially pathogenic gramnegative aerobic bacteria.

METHODS: Fresh faecal specimens were obtained from 61 infants in Addis Abeba and 21 infants in Stockholm. All infants were breastfed. The specimens were frozen for 0-20 days, thawed and transported in anaerobic athmosphere to the laboratory in Stockholm. RESULTS: In Stockholm, the dominating aerobe was S.epidermidis: and the dominating anaerobe was Bacteriodes fragilis. Bifidobacteria were only rarely isolated. In Addis Abeba E.c.oli and lactobacilli dominated. Antibiotic treatment produced no consistent change of the intestinal microflora of Addis Abeba infants, as opposed to the dramatic impact seen in Sweden. There was an inverse relationship between colonization by potentially pathogenic Gramnegative aerobic bacteria and occurrence of bifidobacteria but not of lactobacilli.

CONCLUSIONS: The intestinal flora of breastfed newborn infants in Stockholm differs from what has previously been reported, whereas in Addis Abeba it is more "classical". Bifidobacteria, but not lactobacilli, might produce some resistance to colonization by Gramnegative bacteria from the hospital environment. 